\title{
Environmental Protection and Management in Coastal and Maritime Industries
}

\author{
Aboul Dahab 0* and Shaaban N \\ Oceanography Department, University of Alexandria, Egypt
}

Submission: August 10, 2017; Published: November 17, 2017

*Corresponding author: Aboul Dahab 0, Oceanography Department, Faculty of Science, University of Alexandria, Alexandria, Egypt, Email: ossama_ad@hotmail.com

\begin{abstract}
The present work summarizes the practices that may ensure environmetal protection and management in coastal and maritime industries. These practices include Environmental Impact Assessments (EIAs)/Socio-economic Impact Assesments (SIAs)/Health, Safety and Environmental Impact Assessments (HSEIAs), Environmental Management Systems (EMS)/Health, Safety and Environmental Management systems (HSEMS), Environmental Performance Evaluation (EPE), Environmental Monitoring and auditing and Environmental Reporting. The work also articulates the links and integration between these practices for better coastal and marine pollution prevention. After reviewing the above mentioned practices, we recommend the coastal and maritime industries to consider the integration between EIA and EMS to achieve sustaiable development.
\end{abstract}

\section{Introduction}

The protection of the coastal and marine environment is an essential part of development, without adequate environmental protection, development is undermined and without development resources will be inadequate, and environmental protection will fail [1].

Coastal and maritime industries are increasingly concerned with achieving and demonstrating sound environmental performance by controlling the impacts of their activities, products and services on the environment, consistent with their environmental policy and objectives [2]. Generally speaking, environmental protection is the practice of protecting the natural environment on individual, company or governmental levels, for the benfit of both the environment and humans, while environmental management is a process that coastal and maritime companies undertake to regulate and protect the natural world [3]. It is the process of taking steps and promoting behaviours that will have a positive impact on how environmental resources are used and protected. There are several risks and opprtunities for companies and facilities with regard to the implementation of environmental protection and management practices. Risks may include loss of access to markets and weakness in competitive position and reputation, while opportunities may imply on cost savings and other commercial benefits and enhancement of company image.

\section{Objectives}

This work is an attempt to answer the difficult question «How to use and exploit the coastal and marine resources with minimal environmental impact ?». It also focuses on and summarizes the best practices and their perspectives, linkages and integration that may ensure environmental protection and management in coastal and maritime companies and facilities.

\section{Methodology}

This work is prepared using descriptive approach in addition to the writers knowledge and experience in the area of marine pollution and its control.

\section{Results and Discussion}

The «best practices» in our opinion that may ensure pollution prevention and environmental protection and management in coastal and maritime industries are:

I. Environmental Impact Assessment (EIA)/Socioeconomic Impact Assessment (SIA)/Health, Safety and environmental Impact Assessment (HSEIA).

II. Environmental Management Systems (EMS)/Health, Safety and Environmental Management Systems (HSEMS),

III. Environmental Performance Evaluation (EPE),

IV. Environmental Monitoring and Auditing, and

V. Environmental Reporting.

EIA is a process of evaluation of the likely impacts of a proposed project or development, taking to account interrelated socio-economic, cultural and human health impacts, both beneficial and adverse. SIA highlights the interaction of social and economic factors in the impact assessment process. 
HSEIA is a systematic process of identifying the impact of existing, new or sustaintially altered projects related to health, safety and the environment. One of the main objectives of a HSEIA report is to demonstrate that environmental impacts have been systematiclly identified, assessed and mitigated.

Table 1: EIA and EMS in Perspective.

\begin{tabular}{|c|c|}
\hline \multicolumn{1}{|c|}{ EMS } & EIA \\
\hline Focus on environmental aspects & Focus on environmental impacts \\
\hline Voluntarily introduced & Often required by law \\
\hline $\begin{array}{c}\text { Impacts considered enough for } \\
\text { management to prioritize them }\end{array}$ & Examines impact by details \\
\hline $\begin{array}{c}\text { Focus on continuous } \\
\text { improvement \& updating the } \\
\text { system }\end{array}$ & $\begin{array}{c}\text { The EIS (Environmental Impact } \\
\text { Statement) always tends to be a } \\
\text { static document }\end{array}$ \\
\hline
\end{tabular}

EMS is a part of an overall management system which includes organizational structure, planning activities, responsibilities, practices, procedures, processes and resources for developing, implementing, achieving, reviewing and maintaining the environmental policy at a company or facility or organization level [2]. It is important here to comment on the EIA- EMP (Environmental Management Plan) - EMS linkages. While EIA output provides summary of potential and sigificant environmental impacts as well as suggested mitigation with an EMP. This EMP serves as basis for post-project monitoring and reference for performance evaluation within an EMS. Normally an EMP is a part of EIA report. It details significant impacts, mitigation, compensation and continual improvement actions as identified by EIA.The perspective behined EIA and EMS is given in Table 1.

Integrating EIA and EMS can keep negative impacts within acceptable limits, guarantee continual project design improvements, process refinements, and mitigation measures and enforce approval conditions by regulatory bodies in operation phase. In addition, EMS makes the enforcement (lacking in EIA) of environmental mandate possible. To achieve better environmental protection and management in coastal and maritime industries we recommend the companies to consider the integration between EIAs and EMS. Achieving integration is possible through a system that ensures negative impacts are predicted and mitigated as part of EIA, and that any residual impacts are managed through a continuous improvement process- a major feature in EMS.

HSEMS provides a framework for managing occupational health, safety and environmental issues. It helps in achieving continuous health, safety and environment improvement. EPE is a process designed for ongoing measurement and improvement of environmental performance against set criteria [4]. EPE requires the choice of appropriate indicators for measuring environmental impacts. The necessary indicators include environmental management indicators (EMI), Environmental performance indicators (EPI), and environmental indicators focusing on the state of the environment.

Environmental monitoring and auditing involves regular examination of management systems, operational activities, and their impacts on the environment. This may include monitoring of discharges, emission levels, wastes...etc, toxicity in water bodies affected by pollutants, EIAs implementation to ensure mitigation measures are achieved, and EMS process itself. In addition, environmental monitoring results help in evaluation and update of mitigation strategies. Environmental auditing is the practice of comparing environmental regulatory and management requirements against the operational and record of facility evaluating such records and systems against predetermined standards [5].

Environmental reporting can be mandatory disclosures or voluntary reporting initiatives on release and transfer of toxic/ harmful polluting substances and also on environmental, social, and economic issues assessed holistically.

\section{References}

1. Aboul Dahab O (2017) Sustainable development and planning for coastal and marine environment resources protection. Green Sustainable Cities. $8^{\text {th }}$ Environmental forum of Alexandria University. Alexandria University, Alexandria, Egypt.

2. ISO 1401 (2004) Environmental management systems - Requirements with guidance for use.

3. Aboul Dahab 0 (2013) Environmental protection measures in the field of offshore oil industry. OMICs Group. International conference on oceanography and natural disasters. Orlando, Florida, USA.

4. ISO 14031 (1999) Environmental performance evaluation guidelines.

5. ISO 14012 (1996) Guidelines for environmental auditing-Qualification criteria for environmental auditors. 
Your next submission with Juniper Publishers will reach you the below assets

- Quality Editorial service

- Swift Peer Review

- Reprints availability

- E-prints Service

- Manuscript Podcast for convenient understanding

- Global attainment for your research

- Manuscript accessibility in different formats

( Pdf, E-pub, Full Text, Audio)

- Unceasing customer service

Track the below URL for one-step submission https://juniperpublishers.com/online-submission.php 